\title{
Magnesium and calcium deficiencies additively increase zinc concentrations and metallothionein expression in the rat liver
}

\author{
Megumi Kotani, Ki Hyun Kim, Natsumi Ishizaki, Masayuki Funaba and Tohru Matsui* \\ Division of Applied Biosciences, Graduate School of Agriculture, Kyoto University, Kitashirakawa Oiwake-cho, \\ Kyoto 606-8502, Japan \\ (Submitted 18 August 2011 - Final revision received 17 February 2012 - Accepted 1 March 2012 - First published online 9 May 2012)
}

\section{Abstract}

$\mathrm{Mg}$ deficiency increases the concentration of $\mathrm{Zn}$ in the liver. We investigated the effect of $\mathrm{Mg}$ deficiency on the expression of $\mathrm{Zn}$-regulating factors such as $\mathrm{Zn}$ transporters and metallothionein (MT) in the rat liver. Because Ca deficiency alleviates some of the effects of Mg deficiency, we also investigated the interactions associated with $\mathrm{Ca}$ and $\mathrm{Mg}$ deficiencies. Growing male rats were given a control diet, a Mg-deficient diet, a Ca-deficient diet and a Mg- and Ca-deficient diet for 3 weeks. $\mathrm{Mg}$ and Ca deficiencies additively increased the mRNA levels of MT-1 and MT-2, the MT protein concentration and the concentration of $\mathrm{Zn}$ in the liver. The hepatic mRNA level of Zip14 increased with Mg deficiency but not with Ca deficiency. The dietary treatments did not affect the mRNA levels of other Zn transporters such as Zip1, Zip5, ZnT1, ZnT5 and ZnT6 in the liver. Ca deficiency was found to decrease the amount of femoral Zn and increase serum $\mathrm{Zn}$ concentration. This did not occur in the case of Mg deficiency. These results suggest that Mg deficiency enhances hepatic $\mathrm{Zn}$ uptake by the up-regulation of Zip14 expression and increases hepatic Zn concentration, leading to the enhancement of MT expression. Ca deficiency causes a transfer of $\mathrm{Zn}$ from the bone to the liver, which increases hepatic $\mathrm{Zn}$ concentration and, in turn, up-regulates the expression of MT. Because Mg and Ca deficiencies increase hepatic Zn concentration and increase MT expression by different mechanisms, their effects are additive.

Key words: Calcium deficiency: Liver zinc: Magnesium deficiency: Metallothionein: Rats: Zinc transporter

$\mathrm{Mg}$ deficiency is known to disturb $\mathrm{Zn}$ metabolism. $\mathrm{Mg}$ deficiency increases the concentration of $\mathrm{Zn}$ in the liver ${ }^{(1-3)}$, while $\mathrm{Zn}$ concentration decreases in the testis ${ }^{(1)}$ and the heart ${ }^{(2)}$. Although the liver plays a central role in the metabolism of $\mathrm{Zn}$, it has not been clarified how $\mathrm{Mg}$ deficiency enhances $\mathrm{Zn}$ accumulation in the liver.

Metallothionein (MT) is a cysteine-rich, low-molecular-weight protein consisting of four isoforms. Isoforms MT-1 and MT-2 are expressed in the liver ${ }^{(4)}$ and are known to have diverse functions in $\mathrm{Zn}$ homeostasis and in protection against heavy metal toxicity and oxidative stress ${ }^{(5)}$. The expression of MT is up-regulated by metals, including $\mathrm{Zn}$, and by oxidative stress in the liver ${ }^{(6)}$. Because $\mathrm{Mg}$ deficiency is known to induce oxidative stress in the liver ${ }^{(3,7,8)}$, it has been speculated that oxidative stress caused by $\mathrm{Mg}$ deficiency would increase hepatic $\mathrm{Zn}$ concentration through the up-regulation of MT expression ${ }^{(3)}$.

Solute carrier family 39 members such as $\mathrm{Zip}^{(9)}, \mathrm{Zip}^{(10)}$ and Zip14 ${ }^{(11)}$ and solute carrier family 30 members such as ZnT1 ${ }^{(12)}$, $\mathrm{ZnT5}^{(13)}$ and $\mathrm{ZnT6}^{(14)}$ are expressed in the liver. Solute carrier family 39 members increase the cytosolic $\mathrm{Zn}$ concentration by importing $\mathrm{Zn}$ into the cytosol from the extracellular fluid or intracellular organelles, and solute carrier family 30 members decrease the cytosolic $\mathrm{Zn}$ concentration by promoting $\mathrm{Zn}$ efflux from the cytosol ${ }^{(15)}$. Thus, these transporters affect $\mathrm{Zn}$ metabolism in the liver. However, the effect of $\mathrm{Mg}$ deficiency on the expression of $\mathrm{Zn}$ transporters has not been reported.

$\mathrm{Mg}$ frequently acts as a natural $\mathrm{Ca}$ antagonist ${ }^{(16)}$, and $\mathrm{Ca}$ deficiency has been reported to ameliorate some of the effects of $\mathrm{Mg}$ deficiency ${ }^{(17)}$. Therefore, simultaneous $\mathrm{Ca}$ and $\mathrm{Mg}$ deficiency possibly suppresses $\mathrm{Zn}$ accumulation observed in the liver of Mg-deficient animals.

We performed an investigation to clarify the effects of $\mathrm{Mg}$ and $\mathrm{Ca}$ deficiencies, and the effects of their interactions on the $\mathrm{Zn}$ concentration and the expression of MT and $\mathrm{Zn}$ transporters in the rat liver.

\section{Materials and methods}

\section{Animals and diets}

A total of twenty-four male-specific pathogen-free SpragueDawley rats aged 4 weeks were purchased from SLC Japan

Abbreviations: AIN-93G, American Institute of Nutrition-93G; CAD, calcium deficiency; Gapdh, glyceraldehyde-3-phosphate dehydrogenase; MCD, magnesium and calcium deficiency; MGD, magnesium deficiency; MT, metallothionein; TBARS, thiobarbituric acid-reactive substances. 
and cared for according to the Guide for the Care and Use of Laboratory Animals (Animal Care Committee, Kyoto University). The rats were individually housed in stainless-steel cages in a temperature-, humidity- and light-controlled room $\left(24^{\circ} \mathrm{C}, 60 \%\right.$ and $12 \mathrm{~h}$ light $-12 \mathrm{~h}$ dark cycle, respectively). All rats were fed the American Institute of Nutrition-93G (AIN-93G) diet ${ }^{(18)}$ for a $5 \mathrm{~d}$ adaptation period. Then, the animals were divided into four groups of six rats as a $2 \times 2$ factorial arrangement (two dietary $\mathrm{Mg}$ levels and two dietary Ca levels): one group was given the control diet, another group was fed a Mg-deficient (MGD) diet, another group was fed a Ca-deficient (CAD) diet and the remaining group was fed a $\mathrm{Mg}$ - and $\mathrm{Ca}$-deficient $(\mathrm{MCD})$ diet. These diets were prepared on the basis of the AIN-93G diet ${ }^{(18)}$ with the Mg- and Ca-free AIN-93G mineral premix. MgO was added at $26 \cdot 1 \mathrm{mmol} / \mathrm{kg}$ for the control and CAD diets at the expense of maize starch. $\mathrm{CaCO}_{3}$ was added at $130 \mathrm{mmol} / \mathrm{kg}$ for the control and MGD diets and at $13 \mathrm{mmol} / \mathrm{kg}$ for the CAD and MCD diets. The dietary concentrations of $\mathrm{Mg}$, $\mathrm{Ca}$ and $\mathrm{Zn}$ are shown in Table 1 . The animals were pair-fed with their respective experimental diets adjusted to match the feed intake of the MGD group for 3 weeks. The rats were allowed free access to demineralised water during the experiment.

\section{Data and sample collection}

We measured feed intake and body weight during the experiment. Feed efficiency was calculated from the ratio of weight gain:feed intake. Inflammatory skin lesions were evaluated by the inflammatory score ${ }^{(19)}$ with a slight modification based on the following criteria: 0 points, no skin lesion; 1 point, hyperaemia of one ear accompanied by swelling; 2 points, hyperaemia of both ears accompanied by swelling; 3 points, inflammation of one ear, including slough; 4 points, inflammation of both ears, including slough; 5 points, inflammation of both ears and tail.

Under isoflurane anaesthesia, a blood sample was obtained from the abdominal aorta with a plastic syringe at the end of the experiment. Serum was separated by centrifugation at $3000 \mathrm{~g}$ for $30 \mathrm{~min}$ at $4^{\circ} \mathrm{C}$. The left femur was removed, cleaned of adhering tissues and weighed. The serum and femur samples were stored at $-20^{\circ} \mathrm{C}$ until analyses. The liver was promptly excised, weighed, washed with ice-cold isotonic saline, placed in liquid $\mathrm{N}_{2}$ and stored at $-80^{\circ} \mathrm{C}$ until analyses.

\section{Determination of minerals, thiobarbituric acid-reactive substances and metallothionein protein}

The liver, femur, serum and diet samples were wet-digested with trace element-grade $\mathrm{HNO}_{3}$ and $\mathrm{H}_{2} \mathrm{O}_{2}$ (Wako Chemicals).

Table 1. Mineral concentration of the experimental diets ( $\mathrm{mmol} / \mathrm{kg}$ diet)

\begin{tabular}{lcccc}
\hline & \multicolumn{4}{c}{ Diets } \\
\cline { 2 - 5 } & Control & MGD & CAD & MCD \\
\hline $\mathrm{Ca}$ & 136.3 & 131.7 & 13.1 & 13.2 \\
$\mathrm{Mg}$ & 20.37 & 1.69 & 20.29 & 1.65 \\
$\mathrm{Zn}$ & 0.61 & 0.61 & 0.61 & 0.61 \\
\hline MGD, Mg-deficient; & CAD, & Ca-deficient; & MCD, & Mg- and Ca- \\
\multicolumn{2}{l}{ deficient. }
\end{tabular}

Then, we determined the $\mathrm{Mg}$, Ca and $\mathrm{Zn}$ concentrations in the serum and tissue samples with an atomic absorption spectrophotometer (AA-6600F; Shimadzu).

The liver samples were homogenised in chilled saline and the homogenate was centrifuged at $105000 \mathrm{~g}$ for $30 \mathrm{~min}$ at $4^{\circ} \mathrm{C}$ (CS100X; Hitachi Koki). The concentration of thiobarbituric acid-reactive substances (TBARS) in the supernatant was determined using a commercial kit (OXI-TEK TBARS Assay Kit; ZeptoMetrix) according to the instruction manual.

The total hepatic MT protein concentration was determined according to the Cd-Chelex method ${ }^{(20,21)}$. Briefly, the liver samples were homogenised in a $250 \mathrm{~mm}$-sucrose solution on ice and centrifuged at $105000 \mathrm{~g}$ for $60 \mathrm{~min}$ at $4^{\circ} \mathrm{C}$. The supernatant was mixed with $0.55 \mathrm{~mm}-\mathrm{CdCl}_{2}$ in $20 \mathrm{~mm}$-Tris- $\mathrm{HCl}$ buffer ( $\mathrm{pH} 8$ ), incubated for $10 \mathrm{~min}$ at room temperature, and then heated at $100^{\circ} \mathrm{C}$ for $3 \mathrm{~min}$. After cooling, the mixture was centrifuged at $8000 \mathrm{~g}$ for $10 \mathrm{~min}$ at $4^{\circ} \mathrm{C}$. Then, $16 \mathrm{mg} / \mathrm{ml}$ of the ion-exchange resin (Chelex 100; Bio-Rad Japan) were added to the supernatant and shaken for $30 \mathrm{~min}$. The resin and precipitate were removed by centrifugation at $8000 \mathrm{~g}$ for $10 \mathrm{~min}$ at $4^{\circ} \mathrm{C}$. The Cd concentration in the supernatant was determined as the form binding to MT by an inductively coupled plasma mass spectrometer (Elan 6000; Perkin Elmer). The protein concentration of MT was calculated using a molecular weight of 6600 for MT and the assumption that $7 \mathrm{~g}$ of $\mathrm{Cd}$ atoms corresponds to $1 \mathrm{~mol}$ of $\mathrm{MT}^{(20)}$.

\section{RNA preparation and quantitative $R T-P C R$}

Total RNA was extracted from the liver samples with TRIzol reagents (Invitrogen) according to the manufacturer's protocol. Absorbance at $260 \mathrm{~nm}$ was measured to quantify the RNA concentration, and simultaneously the ratio of absorbance at $260 \mathrm{~nm}$ to that at $280 \mathrm{~nm}$ was monitored to assess the purity of RNA. Quantitative RT-PCR was carried out as described previously $^{(22)}$. The gene transcripts of $M T-1, M T-2, Z i p 1, Z i p 5$, Zip14, ZnT1, ZnT5, ZnT6 and glyceraldehyde-3-phosphate dehydrogenase (Gapdb) were amplified by complementary DNA-specific primers (Table 2). The relative levels of gene expression were normalised against the mRNA level of Gapdh.

\section{Statistical analyses}

Statistical analyses (except for the inflammation score) were performed using SAS statistical software (version 9.1; SAS Institute). Results are expressed as means with their standard errors. Data reflecting mRNA levels were log-transformed to provide an approximation of a normal distribution before the analysis. The data were analysed as a $2 \times 2$ factorial using the general linear model procedure. The statistical model included the main effects of dietary $\mathrm{Mg}$, dietary $\mathrm{Ca}$ and their interaction. When an interaction was significant, the significant differences between means were evaluated using a multiple comparison procedure (Student-Newman-Keuls) or the significant difference between two means was evaluated using the two-sided $t$ test. The inflammation score data are expressed as means with their standard errors, and a significant difference between groups was determined each day by the Steel-Dwass test ${ }^{(23)}$. 
Table 2. Sequence of the PCR primers for amplification

\begin{tabular}{|c|c|c|c|}
\hline Genes & Forward primer & Reverse primer & GenBank accession no. \\
\hline MT-1 & 5'-CACCAGATCTCGGAATGGAC-3' & 5'-GCAGCAGCTCTTCTTGCAG-3' & NM_138826 \\
\hline MT-2 & 5'-АCСTССTGCAAGAAAAGCTG-3' & 5'-ACTTGTCCGAAGCCTCTTTGG-3' & NM_001137564 \\
\hline Zip1 & 5'-CCTGGCTACCTGTCTTCTGG-3' & 5'-CTCTTGCAAGGGGAACTGAA-3' & NM_001134577 \\
\hline Zip5 & 5'-CCTCGGGCCTAGACCTCTT-3' & 5'-AGCTGGGAACCATTCAGACA-3' & NM_001108728 \\
\hline Zip14 & 5'-TTCCTCAGTGTCTCACTGATTAA-3' & 5'-GGAAAAGTGCGTTAGAGAGC-3' & NM_001107275 \\
\hline ZnT1 & 5'-AACACCAGCAATTCCAACG-3' & 5'-CCACTGGATCATCACTTCTCAA-3' & NM_022853 \\
\hline ZnT5 & 5'-TGACACAAACATGCTGACACC- $3^{\prime}$ & 5'-CATGACTGTGGGCGTGACT-3' & NM_001106404 \\
\hline ZnT6 & 5'-GTGCCATCAACGTGCTGT-3' & 5'-GGTGAGGTAAGTATAAGCAGTTAAAG-3' & NM_001106708 \\
\hline Gapdh & $5^{\prime}$-ACAACTTTGGCATCGTGGA-3' & 5'-CTTCTGAGTGGCAGTGATGG-3' & NM_017008 \\
\hline
\end{tabular}

MT, metallothionein; Gapdh, glyceraldehyde-3-phosphate dehydrogenase.

When all rats in more than two groups had no inflammation, the data of one group were adopted as representative data in the statistical analysis because of methodological limitations. Statistical significance was considered to be $P<0 \cdot 05$.

\section{Results}

No skin lesions were observed in the control group and in the CAD group throughout the experiment. The inflammation score in the MGD group was significantly higher than that in the MCD group on day $4(P<0 \cdot 05)$; this score peaked on day 5 and had essentially disappeared by day 13 (Fig. 1). Although two rats in the MCD group had a relatively high score on the last $2 \mathrm{~d}$, the inflammation score did not differ significantly among the control, CAD and MCD groups throughout the experiment.

The dietary treatments did not significantly affect the final body weight (Table 3). Ca deficiency and Mg deficiency did

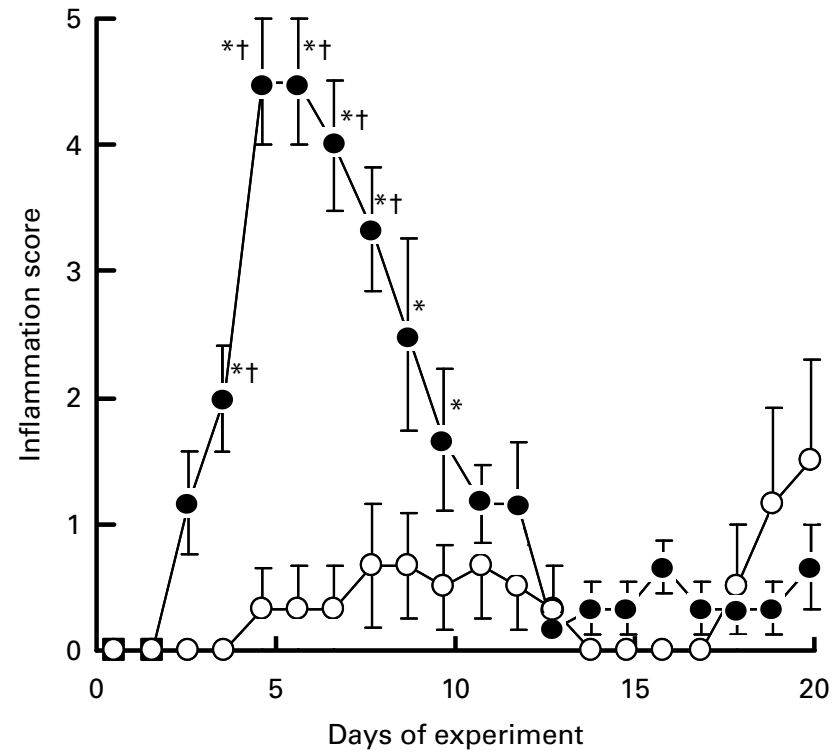

Fig. 1. Effects of magnesium and calcium deficiencies on the inflammation score in the skin of rats. Values are means, with their standard errors represented by vertical bars $(n 6)$. * Mean values were significantly different from the control and the calcium-deficient groups $(P<0.05)$. † Mean values were significantly different from the magnesium- and calcium-deficient group $(P<0.05)$. Lesions were not observed in the control group and the calciumdeficient group throughout the experimental period. - - , Magnesiumdeficient group; - $\mathrm{-}$, magnesium- and calcium-deficient group. not affect the body-weight gain. However, the interaction between $\mathrm{Ca}$ and $\mathrm{Mg}$ deficiency was significant $(P=0 \cdot 029)$. Body-weight gain did not differ among the control, CAD and MCD groups but it was significantly lower in the MGD group than in the other groups $(P<0.05)$. The dietary treatments did not affect feed intake because the animals were pair-fed Therefore, feed efficiency was similarly affected as bodyweight gain by the dietary treatments.

Serum Mg concentration was significantly decreased by $\mathrm{Mg}$ deficiency $(P<0 \cdot 001)$ but was significantly increased by $\mathrm{Ca}$ deficiency $(P<0 \cdot 001)$ (Table 4$)$. The interaction between $\mathrm{Ca}$ and $\mathrm{Mg}$ deficiency was also significant $(P=0 \cdot 008)$. Serum $\mathrm{Mg}$ concentration was significantly lower in the Mg-deficient groups than in the Mg-sufficient groups $(P<0.05)$. The CAD group had a significantly higher serum $\mathrm{Mg}$ concentration than the control group $(P<0 \cdot 05)$. Although the multiple comparison analysis showed that serum $\mathrm{Mg}$ concentration did not differ significantly between the MCD and MGD groups, the Mg concentration was $40 \%$ higher ( $P=0.01$ by $t$ test) in the MCD group than in the MGD group. The dietary treatments did not affect serum Ca concentration. The dietary Ca concentration had a significant effect on serum $\mathrm{Zn}$ concentration $(P<0.001)$; Ca deficiency significantly increased serum $\mathrm{Zn}$ concentration. On the other hand, Mg deficiency did not affect serum Zn concentration and did not affect the increase in serum $\mathrm{Zn}$ concentration caused by Ca deficiency.

Ca deficiency significantly decreased the femoral weight ( $P=0.009$ ); however, $\mathrm{Mg}$ deficiency did not affect either the femoral weight or the reduction of femoral weight caused by $\mathrm{Ca}$ deficiency. The amount of femoral $\mathrm{Mg}$ was significantly decreased by either $\mathrm{Mg}$ or Ca deficiency $(P<0 \cdot 001)$. The interaction between $\mathrm{Ca}$ and $\mathrm{Mg}$ deficiency was also significant $(P<0 \cdot 001)$. The Mg-deficient groups had significantly smaller amounts of femoral $\mathrm{Mg}$ than the Mg-sufficient groups $(P<0.05)$. Femoral $\mathrm{Mg}$ was significantly lower in the CAD group than in the control group $(P<0.05)$. Additionally, the amount of $\mathrm{Mg}$ was significantly lower in the MCD group than in the MGD group $(P<0 \cdot 05)$. Ca deficiency significantly affected the amount of femoral $\mathrm{Ca}(P<0 \cdot 001)$; Ca deficiency decreased the amount of $\mathrm{Ca}$. Mg deficiency did not affect the amount of femoral $\mathrm{Ca}$ and the extent of decreased femoral $\mathrm{Ca}$ by Ca deficiency. The amount of femoral $\mathrm{Zn}$ was significantly decreased by $\mathrm{Ca}$ deficiency $(P=0.026)$ but was slightly increased by $\mathrm{Mg}$ deficiency $(P=0 \cdot 007)$. An interaction between Ca deficiency and Mg deficiency was not observed. 
Table 3. Effects of magnesium and calcium deficiencies on growth parameters in rats*

(Mean values with their standard errors, $n 6$ )

\begin{tabular}{|c|c|c|c|c|c|c|c|c|c|c|c|}
\hline Groups... & \multicolumn{2}{|c|}{ Control } & \multicolumn{2}{|c|}{ MGD } & \multicolumn{2}{|c|}{ CAD } & \multicolumn{2}{|c|}{ MCD } & & & \\
\hline Dietary Mg level... & \multicolumn{2}{|c|}{ Sufficient } & \multicolumn{2}{|c|}{ Deficient } & \multicolumn{2}{|c|}{ Sufficient } & \multicolumn{2}{|c|}{ Deficient } & & & \\
\hline \multirow[t]{2}{*}{ Dietary Ca level... } & \multicolumn{2}{|c|}{ Sufficient } & \multicolumn{2}{|c|}{ Sufficient } & \multicolumn{2}{|c|}{ Deficient } & \multicolumn{2}{|c|}{ Deficient } & \multicolumn{3}{|c|}{ Effect $(P)$} \\
\hline & Mean & SEM & Mean & SEM & Mean & SEM & Mean & SEM & $\mathrm{Mg}$ & $\mathrm{Ca}$ & $\mathrm{Mg} \times \mathrm{Ca}$ \\
\hline Initial body weight (g) & $105 \cdot 4$ & 3.9 & $105 \cdot 5$ & 3.3 & $106 \cdot 1$ & 1.6 & $105 \cdot 8$ & 3.9 & 0.875 & 0.982 & 0.950 \\
\hline Final body weight (g) & $177 \cdot 7$ & $5 \cdot 6$ & $170 \cdot 0$ & 2.5 & 177.4 & $2 \cdot 6$ & $179 \cdot 2$ & $3 \cdot 7$ & 0.252 & 0.450 & 0.229 \\
\hline Weight gain $(\mathrm{g} / \mathrm{d})$ & $3.62^{\mathrm{a}}$ & 0.15 & $3 \cdot 23^{b}$ & 0.08 & $3.57^{\mathrm{a}}$ & 0.11 & $3.67^{\mathrm{a}}$ & 0.07 & 0.071 & 0.188 & 0.029 \\
\hline Feed intake $(\mathrm{g} / \mathrm{d})$ & $11 \cdot 7$ & 0.1 & 11.5 & 0.1 & $11 \cdot 6$ & $0 \cdot 1$ & $11 \cdot 6$ & $0 \cdot 1$ & 0.808 & 0.157 & 0.325 \\
\hline Feed efficiency $(\mathrm{g} / \mathrm{g})$ & $0.31^{\mathrm{a}}$ & 0.01 & $0.28^{\mathrm{b}}$ & 0.01 & $0.31^{\mathrm{a}}$ & 0.01 & $0.32^{\mathrm{a}}$ & 0.01 & 0.365 & 0.381 & 0.023 \\
\hline
\end{tabular}

MGD, Mg-deficient; CAD, Ca-deficient; MCD, Mg- and Ca-deficient.

${ }^{a, b}$ Mean values within a row with unlike superscript letters were significantly different $(P<0.05)$.

* When an interaction was significant, the significant differences among means were evaluated using the Student-Newman-Keuls test

The dietary treatments did not affect the liver weight (Table 5). Either $\mathrm{Mg}$ or $\mathrm{Ca}$ deficiency significantly increased the $\mathrm{Zn}$ concentration in the liver (Mg deficiency, $P=0.009$; Ca deficiency, $P=0.004)$. An interaction was not observed, indicating that $\mathrm{Mg}$ and $\mathrm{Ca}$ deficiencies additively increase hepatic $\mathrm{Zn}$ concentrations. Because the dietary treatments did not affect the liver weight, the amount of hepatic Zn was similarly affected as its concentration by the dietary treatments. Either Mg or Ca deficiency increased the concentration of MT protein in the liver (Mg deficiency, $P=0.001$; Ca deficiency, $P=0.003$ ). An interaction was not observed, indicating that $\mathrm{Mg}$ and $\mathrm{Ca}$ deficiencies additively increase the MT protein concentrations. Hepatic TBARS concentration was increased by Mg deficiency $(P=0.034)$, but $\mathrm{Ca}$ deficiency affected neither the hepatic TBARS concentration nor the extent of increased TBARS concentration by Mg deficiency.

The mRNA level of $M T-1$ was significantly increased by either $\mathrm{Mg}$ or Ca deficiency in the liver (Mg deficiency, $P<0 \cdot 001$; Ca deficiency, $P=0.001)$ and an interaction was not observed (Table 6). The mRNA level of $M T-2$ was significantly increased by either $\mathrm{Mg}$ or $\mathrm{Ca}$ deficiency in the liver $(P<0.001)$ and an interaction was not observed. These results indicate that $\mathrm{Mg}$ and $\mathrm{Ca}$ deficiencies additively increase the mRNA levels of $M T-1$ and MT-2. Mg deficiency was found to significantly increase the hepatic mRNA level of Zip14 $(P=0.014)$ but $\mathrm{Ca}$ deficiency affected neither the mRNA level of Zip14 nor the increase in mRNA level caused by Mg deficiency. The dietary treatments did not affect the mRNA levels of Zip1, Zip5, $Z n T 1, Z n T 5$ and $Z n T 6$, indicating that the increased hepatic $\mathrm{Zn}$ concentration caused by $\mathrm{Ca}$ or $\mathrm{Mg}$ deficiency is not related to the mRNA levels of these transporters.

\section{Discussion}

Although Mg deficiency did not affect serum Zn concentration, $\mathrm{Mg}$ deficiency increased hepatic Zn concentration and the Zip14 mRNA level without affecting the mRNA levels of the other Zn transporters. Zip14 imports Zn into the cytosol through the plasma membrane in the liver ${ }^{(15)}$. The suppression of Zip14 expression by a specific small interfering RNA decreases the

Table 4. Effects of magnesium and calcium deficiencies on mineral concentrations in serum and the amount of mineral in rat femur $\dagger$ (Mean values with their standard errors, $n 6$ )

\begin{tabular}{|c|c|c|c|c|c|c|c|c|c|c|c|}
\hline Groups... & \multicolumn{2}{|c|}{ Control } & \multicolumn{2}{|c|}{ MGD } & \multicolumn{2}{|c|}{ CAD } & \multicolumn{2}{|c|}{ MCD } & & & \\
\hline Dietary Mg level. . & \multicolumn{2}{|c|}{ Sufficient } & \multicolumn{2}{|c|}{ Deficient } & \multicolumn{2}{|c|}{ Sufficient } & \multicolumn{2}{|c|}{ Deficient } & & & \\
\hline \multirow[t]{2}{*}{ Dietary Ca level... } & \multicolumn{2}{|c|}{ Sufficient } & \multicolumn{2}{|c|}{ Sufficient } & \multicolumn{2}{|c|}{ Deficient } & \multicolumn{2}{|c|}{ Deficient } & \multicolumn{3}{|c|}{ Effect $(P)$} \\
\hline & Mean & SEM & Mean & SEM & Mean & SEM & Mean & SEM & $\mathrm{Mg}$ & $\mathrm{Ca}$ & $\mathrm{Mg} \times \mathrm{Ca}$ \\
\hline \multicolumn{12}{|l|}{ Serum } \\
\hline $\mathrm{Mg}(\mu \mathrm{mol} / \mathrm{l})$ & $840^{\mathrm{b}}$ & 33 & $226^{\mathrm{c} *}$ & 12 & $1202^{\mathrm{a}}$ & 80 & $313^{\mathrm{c} *}$ & 25 & $<0.001$ & $<0.001$ & 0.008 \\
\hline $\mathrm{Ca}(\mathrm{mmol} / \mathrm{l})$ & $2 \cdot 70$ & 0.14 & 2.85 & 0.09 & 2.69 & 0.12 & 2.35 & 0.25 & 0.577 & 0.129 & 0.156 \\
\hline $\mathrm{Zn}(\mu \mathrm{mol} / \mathrm{l})$ & $26 \cdot 6$ & $1 \cdot 2$ & $24 \cdot 0$ & 0.6 & $36 \cdot 2$ & 1.4 & $33 \cdot 6$ & $3 \cdot 1$ & 0.177 & $<0.001$ & 0.962 \\
\hline \multicolumn{12}{|l|}{ Femur } \\
\hline Wet weight (g/femur) & 0.71 & 0.03 & 0.84 & 0.04 & 0.66 & 0.04 & 0.69 & 0.04 & 0.056 & 0.009 & 0.264 \\
\hline $\mathrm{Mg}(\mu \mathrm{mol} / \mathrm{femur})$ & $44 \cdot 4^{\mathrm{a}}$ & $1 \cdot 2$ & $15 \cdot 2^{\mathrm{C}}$ & 0.8 & $29 \cdot 6^{\mathrm{b}}$ & $1 \cdot 2$ & $10 \cdot 3^{d}$ & 0.8 & $<0.001$ & $<0.001$ & $<0.001$ \\
\hline $\mathrm{Ca}$ (mmol/femur) & 1.66 & 0.05 & 1.73 & 0.02 & 0.90 & 0.03 & 1.00 & 0.03 & 0.203 & $<0.001$ & 0.716 \\
\hline $\mathrm{Zn}(\mu \mathrm{mol} / \mathrm{femur})$ & $1 \cdot 39$ & 0.06 & 1.42 & 0.02 & $1 \cdot 14$ & 0.04 & $1 \cdot 36$ & 0.07 & 0.007 & 0.026 & 0.086 \\
\hline
\end{tabular}

MGD, Mg-deficient; CAD, Ca-deficient; MCD, Mg- and Ca-deficient.

a,b,c,d Mean values within a row with unlike superscript letters were significantly different $(P<0.05)$.

${ }^{*}$ Mean values were significantly different between the two groups $(P=0.01)$.

†When an interaction was significant, the significant differences among means were evaluated using the Student-Newman-Keuls test or the significant difference between two means was evaluated using the two-sided $t$ test. 
Table 5. Effects of magnesium and calcium deficiencies on zinc, metallothionein (MT) and thiobarbituric acid-reactive substance (TBARS) concentrations in the rat liver

(Mean values with their standard errors, $n 6$ )

\begin{tabular}{|c|c|c|c|c|c|c|c|c|c|c|c|}
\hline Groups... & \multicolumn{2}{|c|}{ Control } & \multicolumn{2}{|c|}{ MGD } & \multicolumn{2}{|c|}{$C A D$} & \multicolumn{2}{|c|}{ MCD } & & & \\
\hline Dietary Mg level... & \multicolumn{2}{|c|}{ Sufficient } & \multicolumn{2}{|c|}{ Deficient } & \multicolumn{2}{|c|}{ Sufficient } & \multicolumn{2}{|c|}{ Deficient } & & & \\
\hline \multirow[t]{2}{*}{ Dietary Ca level... } & \multicolumn{2}{|c|}{ Sufficient } & \multicolumn{2}{|c|}{ Sufficient } & \multicolumn{2}{|c|}{ Deficient } & \multicolumn{2}{|c|}{ Deficient } & \multicolumn{3}{|c|}{ Effect $(P)$} \\
\hline & Mean & SEM & Mean & SEM & Mean & SEM & Mean & SEM & $\mathrm{Mg}$ & $\mathrm{Ca}$ & $\mathrm{Mg} \times \mathrm{Ca}$ \\
\hline Wet weight (g/liver) & 6.38 & 0.40 & 6.22 & 0.15 & 6.95 & 0.29 & $7 \cdot 01$ & 0.21 & 0.865 & 0.204 & 0.690 \\
\hline $\mathrm{Zn}(\mu \mathrm{mol} / \mathrm{g})$ & 0.41 & 0.02 & 0.49 & 0.03 & 0.48 & 0.02 & 0.60 & 0.05 & 0.009 & 0.004 & 0.471 \\
\hline Zn ( $\mu \mathrm{mol} /$ liver $)$ & 2.63 & 0.13 & 3.04 & 0.12 & 3.31 & 0.15 & $4 \cdot 18$ & 0.29 & 0.003 & $<0.001$ & 0.240 \\
\hline MT protein $(\mu \mathrm{g} / \mathrm{g})$ & 83.4 & 9.0 & $120 \cdot 6$ & $12 \cdot 3$ & $128 \cdot 1$ & 12.7 & $212 \cdot 2$ & $28 \cdot 2$ & 0.001 & 0.003 & 0.194 \\
\hline TBARS (nmol/g) & 45.4 & 3.2 & $52 \cdot 8$ & 1.7 & $42 \cdot 7$ & $5 \cdot 7$ & $53 \cdot 8$ & 4.5 & 0.034 & 0.834 & 0.658 \\
\hline
\end{tabular}

MGD, Mg-deficient; CAD, Ca-deficient; MCD, Mg- and Ca-deficient.

extent of Zn uptake by hepatocytes ${ }^{(24)}$, and the up-regulation of Zip14 expression is considered to increase the extent of hepatic $\mathrm{Zn}$ accumulation ${ }^{(11)}$. These results suggest that $\mathrm{Mg}$ deficiency increases $\mathrm{Zn}$ uptake by the liver through the up-regulation of Zip14 expression at the mRNA level. Hepatic expression of Zip14 is transcriptionally enhanced by IL-1 $\beta^{(25)}$ and IL- $6^{(11)}$. These cytokine concentrations in the plasma have been reported to increase in rats fed a low-Mg diet for 3 weeks ${ }^{(26)}$. It is possible that the elevation of these cytokine levels up-regulates the mRNA expression of Zip14 in the liver of Mg-deficient rats.

Mg deficiency increases the concentration of MT protein with increasing mRNA levels of $M T-1$ and $M T-2$ in the liver. $M T-1$ transcription is enhanced by increased cytosolic $\mathrm{Zn}$ concentrations and oxidative stress ${ }^{(6)}$. Thus, we consider that the expressions of MT mRNA and MT protein are enhanced by an increased $\mathrm{Zn}$ uptake through the up-regulation of Zip14 expression in the liver of Mg-deficient animals. This is supported by reports showing that overexpression of Zip14 increased the mRNA expression of $M T-1$ via an increased $\mathrm{Zn}$ uptake in HEK 293T cells ${ }^{(11)}$ and that its down-regulation decreased the mRNA expression of $M T-1$ through the suppression of $\mathrm{Zn}$ uptake in cultured hepatocytes ${ }^{(24)}$. Mg deficiency increased hepatic $\mathrm{Zn}$ concentration by $20 \%$ and increased hepatic MT expression by $40 \%$. An experiment using subcutaneous injection with $\mathrm{Zn}$ indicated that MT concentration highly and linearly correlated with $\mathrm{Zn}$ concentration in the liver of rats and that MT concentration largely responded to changes in $\mathrm{Zn}$ concentration ${ }^{(27)}$. Therefore, we consider that the increase in $\mathrm{Zn}$ concentration is enough to explain the enhancement of MT expression in the liver of Mg-deficient rats. Additionally, $\mathrm{Mg}$ deficiency induced oxidative stress, which is reflected by increased TBARS concentrations measured in the present study. This is supported by previous reports $^{(3,7,8)}$. Therefore, it is also likely that oxidative stress partly contributes to the up-regulation of the mRNA expression of MT in the liver of Mg-deficient animals.

Hepatic Zn concentration is 2-fold lower in MT-1- and MT-2null mice than in wild-type mice when excess $\mathrm{Zn}$ is provided, and $72 \%$ of the total $\mathrm{Zn}$ in the liver is associated with MT in the wild-type mice ${ }^{(28)}$. Therefore, the large difference of MT expression probably affects the $\mathrm{Zn}$ concentration in the liver. On the other hand, it has been reported that the total $\mathrm{Zn}$ concentration was not changed in the rat liver even when $\mathrm{Zn}$ bound MT was increased by 5- and 7-fold by cold stress and treatment with $\mathrm{CCl}_{4}$, respectively ${ }^{(29)}$. The administration of lipopolysaccharides has been reported to cause approximately a 12 -fold increase in the mRNA level of $M T-1$ in the mouse liver

Table 6. Effects of magnesium and calcium deficiencies on mRNA levels of metallothionein $(M T)$ and zinc transporters in the rat liver* (Mean values with their standard errors, $n 6$ )

\begin{tabular}{|c|c|c|c|c|c|c|c|c|c|c|c|}
\hline Groups. . . & \multicolumn{2}{|c|}{ Control } & \multicolumn{2}{|c|}{ MGD } & \multicolumn{2}{|c|}{ CAD } & \multicolumn{2}{|c|}{ MCD } & & & \\
\hline Dietary Mg level... & \multicolumn{2}{|c|}{ Sufficient } & \multicolumn{2}{|c|}{ Deficient } & \multicolumn{2}{|c|}{ Sufficient } & \multicolumn{2}{|c|}{ Deficient } & & & \\
\hline \multirow[t]{2}{*}{ Dietary Ca level... } & \multicolumn{2}{|c|}{ Sufficient } & \multicolumn{2}{|c|}{ Sufficient } & \multicolumn{2}{|c|}{ Deficient } & \multicolumn{2}{|c|}{ Deficient } & \multicolumn{3}{|c|}{ Effect $(P)$} \\
\hline & Mean & SEM & Mean & SEM & Mean & SEM & Mean & SEM & $\mathrm{Mg}$ & $\mathrm{Ca}$ & $\mathrm{Mg} \times \mathrm{Ca}$ \\
\hline$M T-1$ & $1 \cdot 00$ & 0.31 & $6 \cdot 87$ & 2.53 & $5 \cdot 30$ & $1 \cdot 23$ & $12 \cdot 24$ & $3 \cdot 23$ & $<0.001$ & 0.001 & 0.222 \\
\hline$M T-2$ & 1.00 & 0.32 & $11 \cdot 38$ & 4.92 & $5 \cdot 87$ & $1 \cdot 11$ & $15 \cdot 23$ & $3 \cdot 10$ & $<0.001$ & $<0.001$ & 0.226 \\
\hline Zip1 & 1.00 & 0.10 & 1.02 & 0.15 & 0.94 & 0.13 & 1.02 & 0.24 & 0.292 & 0.868 & 0.533 \\
\hline Zip5 & 1.00 & 0.55 & 0.62 & 0.10 & 1.53 & 0.54 & 1.00 & 0.13 & 0.068 & 0.907 & 0.668 \\
\hline Zip14 & 1.00 & 0.14 & 1.42 & 0.22 & 1.07 & 0.18 & 1.75 & 0.18 & 0.014 & 0.383 & 0.659 \\
\hline$Z n T 1$ & 1.00 & 0.18 & 0.90 & 0.09 & 0.92 & 0.12 & $1 \cdot 11$ & 0.23 & 0.759 & 0.494 & 0.481 \\
\hline ZnT5 & 1.00 & 0.15 & $1 \cdot 10$ & 0.09 & 1.05 & 0.19 & $1 \cdot 15$ & 0.12 & 0.690 & 0.553 & 0.940 \\
\hline ZnT6 & 1.00 & 0.10 & 0.85 & 0.11 & 0.75 & 0.20 & 0.71 & 0.08 & 0.537 & 0.111 & 0.463 \\
\hline
\end{tabular}


but did not affect the total $\mathrm{Zn}$ concentration ${ }^{(30)}$. Mg deficiency was found to increase the expression of MT protein and MT-1 mRNA by $40 \%$ and 7 -fold, respectively. These results suggest that the increase in MT expression is not enough to increase the $\mathrm{Zn}$ concentration in the liver of Mg-deficient animals. The increase in MT expression does not contribute significantly to increasing the $\mathrm{Zn}$ concentration. We consider that $\mathrm{Mg}$ deficiency increases Zn uptake by enhancing Zip14 expression in the liver, and that MT expression is up-regulated by an increased $\mathrm{Zn}$ concentration and possibly by oxidative stress. Then, MT traps Zn loaded to the liver in Mg-deficient animals.

The levels of circulating $\mathrm{Zn}$ have been reported to decrease immediately after inducing Zip14 expression in the mouse liver $^{(11)}$ and MT expression in the rat liver ${ }^{(29)}$. However, the up-regulation of Zip14 mRNA and MT protein expression did not affect serum $\mathrm{Zn}$ concentration in the Mg-deficient rats. These results suggest that serum $\mathrm{Zn}$ concentration is not affected by the chronic up-regulation of the expression of Zip14 or MT in Mg-deficient rats. An adaptive mechanism of $\mathrm{Zn}$ may prevent hypozincaemia in Mg-deficient rats with chronically enhanced expression of Zip14 or MT.

In contrast to the observations in cases of $\mathrm{Mg}$ deficiency, $\mathrm{Ca}$ deficiency was found to increase serum $\mathrm{Zn}$ concentration along with reducing the amount of femoral $\mathrm{Zn}$. Bone is a major reservoir of $\mathrm{Zn}$ in the body, and Ca deficiency accelerates the release of $\mathrm{Zn}$ from the bone. This is accompanied by bone resorption $^{(31)}$. A low-Ca diet has been reported to increase plasma $\mathrm{Zn}$ concentration ${ }^{(32)}$. This is supported by the present results. Therefore, we suggest that $\mathrm{Ca}$ deficiency increases serum $\mathrm{Zn}$ concentration through the stimulation of bone resorption in the present experiment. The present results indicate that $\mathrm{Ca}$ deficiency increased the concentrations of $\mathrm{Zn}$ and MT in the liver. Furthermore, Ca deficiency increased the mRNA levels of $M T-1$ and $M T-2$ in the liver without affecting the mRNA levels of $\mathrm{Zn}$ transporters. As mentioned above, MT concentration highly and linearly correlated with $\mathrm{Zn}$ concentration in the liver of rats and MT concentration largely responded to changes in $\mathrm{Zn}$ concentration ${ }^{(27)}$. These results suggest that enhanced $\mathrm{Zn}$ supply to the liver increases hepatic $\mathrm{Zn}$ concentration in Ca-deficient rats, leading to the up-regulation of MT expression through increases in the mRNA expressions of $M T-1$ and $M T-2$. Then, hepatic MT traps $\mathrm{Zn}$ supplied from the bone in Ca-deficient animals.

Reductions in dietary $\mathrm{Zn}$ beyond the capacity to maintain homeostasis lead to the utilisation of $\mathrm{Zn}$ from pools located in the bone and the liver ${ }^{(33)}$, and hepatic MT serves as a $\mathrm{Zn}$ reservoir that can be utilised when $\mathrm{Zn}$ is deficient ${ }^{(28)}$. The amount of hepatic $\mathrm{Zn}$ was $0.68 \mu \mathrm{mol}$ higher in the CAD group than in the control group. The amount of $\mathrm{Zn}$ in the left femur was $0.25 \mu \mathrm{mol}$ lower in the CAD group than in the control group; femoral $\mathrm{Zn}$ was $17 \%$ lower in the CAD group than in the control group. According to the equation of House \& Wastney ${ }^{(34)}$, the amount of whole-bone $\mathrm{Zn}$ was calculated to be $23 \mu \mathrm{mol}$ in rats weighing $177 \mathrm{~g}$. This body weight corresponds to the final mean body weight for both groups. Therefore, $\mathrm{Zn}$ loss from the whole bone was estimated to be $3.9 \mu \mathrm{mol}(23 \mu \mathrm{mol}$ multiplied by 0.17 ) during Ca deficiency based on the assumption that each bone responds to Ca deficiency in a similar manner to the femur. These results show that the increase in hepatic Zn corresponds to $17.4 \%(0.68 \mu \mathrm{mol}$ divided by $3.9 \mu \mathrm{mol})$ of $\mathrm{Zn}$ loss from the skeletal tissues. This suggests that the liver only partly saves the released $\mathrm{Zn}$ from the bone during periods of Ca deficiency.

Skin lesions are a clinical sign of inflammation in Mg-deficient rats $^{(35)}$. Mg deficiency-induced skin lesions were observed to appear shortly after the initiation of the experiment. This was resolved by simultaneous $\mathrm{Ca}$ deficiency. Additionally, $\mathrm{Mg}$ deficiency reduced weight gain and feed efficiency, which was also alleviated by simultaneous Ca deficiency. These results indicate that $\mathrm{Ca}$ deficiency rescues the effects of $\mathrm{Mg}$ deficiency on inflammation and growth retardation. $\mathrm{Mg}$ acts as a natural $\mathrm{Ca}$ antagonist $^{(16)}$ and the reduction of the extracellular ratio of $\mathrm{Mg}$ :Ca has been reported to lead to an inflammatory response ${ }^{(36)}$. The dietary restriction of $\mathrm{Ca}$ with hypocalcaemia has been reported to suppress the incidence of skin lesions in Mg-deficient rats, suggesting that hypocalcaemia could be beneficial by decreasing external Ca availability and Ca entry, and thus decreasing the intracellular $\mathrm{Ca}$ concentration in $\mathrm{Mg}$ deficient animals ${ }^{(17)}$. On the other hand, Ca deficiency did not affect serum $\mathrm{Ca}$ concentration in the present experiment probably because Ca levels in Ca-deficient diets were 20-fold higher in the present experiment than in the above-cited report $^{(17)}$. Therefore, it is unlikely that the amelioration of skin lesions and growth retardation are related to the reduction of the antagonistic effect of extracellular Mg on Ca entry in the present experiment. Bones hold the major pool of $\mathrm{Mg}$ in the body and release $\mathrm{Mg}$ in response to $\mathrm{Mg}$ deficiency ${ }^{(37)}$. This is supported by the present results, which indicate that $\mathrm{Mg}$ deficiency causes a significant decrease in femoral $\mathrm{Mg}$ level without affecting the femoral $\mathrm{Ca}$ level. Furthermore, the required dietary $\mathrm{Mg}$ decreases linearly with a reduction in dietary $\mathrm{Ca}$ in rats fed with low-Mg diets (based on the recovery of body-weight gain $)^{(38)}$. The restriction of dietary Ca decreases the amount of femoral $\mathrm{Mg}$ and increases serum $\mathrm{Mg}$ concentration, regardless of the dietary $\mathrm{Mg}$ level in the present experiment. This suggests that the supply of $\mathrm{Mg}$ from the bone to the soft tissues is enhanced by Ca deficiency even in Mg-deficient animals. We suggest that $\mathrm{Ca}$ deficiency ameliorates $\mathrm{Mg}$ deficiency by increasing the Mg supply from the bone. This leads to alleviation of skin lesions and growth retardation. However, it must be noted that the restriction of dietary $\mathrm{Ca}$ did not allow complete recovery from the low concentration of serum $\mathrm{Mg}$ in $\mathrm{Mg}$-deficient rats. The MCD rats remained $\mathrm{Mg}$ deficient.

The MGD and MCD groups suffered severe Mg deficiency and the CAD and MCD groups suffered severe Ca deficiency in the present experiment because the $\mathrm{Mg}$ or Ca concentration in the deficient diets was set as low as $10 \%$ of the requirement levels. $\mathrm{Mg}$ or Ca deficiency shown in the present experiment may not take place actually. On the other hand, Ca deficiency did not affect serum Ca concentration and body-weight gain. These results suggest that $\mathrm{Ca}$ homeostasis is maintained in the Ca-deficient animals and the extent of Ca deficiency did not reach levels to induce pathological conditions in the present experiment. As reviewed by Nielsen ${ }^{(39)}$, severe Mg deficiency induces many pathological conditions in experimental animals 
but subclinical Mg deficiency per se does not. On the other hand, severe $\mathrm{Mg}$ deficiency ( $14 \%$ of the requirement) increased hepatic $\mathrm{Zn}$ concentration within $10 \mathrm{~d}$ in rats and the increase in hepatic $\mathrm{Zn}$ concentration was also observed but delayed when rats suffered moderate Mg deficiency (22\% of the requirement) ${ }^{(3)}$. Therefore, we can postulate that MT and Zip14 mRNA expression is also up-regulated when rats are given a moderate $\mathrm{Mg}$-deficient diet for a long time.

In conclusion, $\mathrm{Mg}$ and $\mathrm{Ca}$ deficiencies up-regulate MT expression in the liver through increasing $\mathrm{Zn}$ uptake by different mechanisms. Mg deficiency up-regulates Zip14 mRNA expression, and Ca deficiency increases the Zn supply from the bone to the liver. As a result, $\mathrm{Mg}$ and $\mathrm{Ca}$ deficiencies additively increase the expression of MT and Zn concentrations in the liver.

\section{Acknowledgements}

The present study received no specific grant from any funding agency in the public, commercial or not-for-profit sectors. M. K. and T. M. designed the research; M. K., N. I., K. H. K. and M. F. conducted the research; M. K. analysed the data; M. K., M. F. and T. M. prepared the manuscript. T. M. had primary responsibility for the final content of the manuscript. All authors read and approved the final manuscript. The authors declare no conflict of interest.

\section{References}

1. Kimura M \& Itokawa Y (1998) Inefficient utilization of iron and minerals in magnesium deficient rats. In Magnesium in Health and Disease, pp. 95-102 [Y Itokawa and J Durlach, editors]. London: John Libbey.

2. Mills BJ, Broghamer WL, Higgins PJ, et al. (1984) Inhibition of tumor growth by magnesium depletion of rats. $J$ Nutr 114, 739-745.

3. Vormann J, Gunther T, Hollriegl V, et al. (1995) Effect of various degrees and duration of magnesium deficiency on lipid peroxidation and mineral metabolism in rats. $J$ Nutr Biochem 6, 681-688.

4. Andersen RD, Taplitz SJ, Birren BW, et al. (1987) Rat metallothionein multigene family. Experientia Suppl 52, 373-384.

5. Vasák M (2005) Advances in metallothionein structure and functions. J Trace Elem Med Biol 19, 13-17.

6. Andrews GK (2000) Regulation of metallothionein gene expression by oxidative stress and metal ions. Biochem Pharmacol 59, 95-104.

7. Calviello G, Ricci P, Lauro L, et al. (1994) Mg deficiency induces mineral content changes and oxidative stress in rats. Biochem Mol Biol Int 32, 903-911.

8. Martin H, Uring-Lambert B, Adrian M, et al. (2008) Effects of long-term dietary intake of magnesium on oxidative stress, apoptosis and ageing in rat liver. Magnes Res 21, 124-130.

9. Jou MY, Hall AG, Philipps AF, et al. (2009) Tissue-specific alterations in zinc transporter expression in intestine and liver reflect a threshold for homeostatic compensation during dietary zinc deficiency in weanling rats. $J$ Nutr 139, 835-841.

10. Wang F, Kim BE, Petris MJ, et al. (2004) The mammalian Zip5 protein is a zinc transporter that localizes to the basolateral surface of polarized cells. J Biol Chem 279, 51433-51441.

11. Liuzzi JP, Lichten LA, Rivera S, et al. (2005) Interleukin-6 regulates the zinc transporter Zip14 in liver and contributes to the hypozincemia of the acute-phase response. Proc Natl Acad Sci U S A 102, 6843-6848.

12. Langmade SJ, Ravindra R, Daniels PJ, et al. (2000) The transcription factor MTF-1 mediates metal regulation of the mouse ZnT1 gene. J Biol Chem 275, 34803-34809.

13. Kambe T, Narita H, Yamaguchi-Iwai Y, et al. (2002) Cloning and characterization of a novel mammalian zinc transporter, zinc transporter 5, abundantly expressed in pancreatic beta cells. J Biol Chem 277, 19049-19055.

14. Huang L, Kirschke CP \& Gitschier J (2002) Functional characterization of a novel mammalian zinc transporter, ZnT6.J Biol Chem 277, 26389-26395.

15. Lichten LA \& Cousins RJ (2009) Mammalian zinc transporters: nutritional and physiologic regulation. Annu Rev Nutr 29, 153-176.

16. Iseri LT \& French JH (1984) Magnesium: nature's physiologic calcium blocker. Am Heart J 108, 188-193.

17. Bussiere FI, Gueux E, Rock E, et al. (2002) Protective effect of calcium deficiency on the inflammatory response in magnesium-deficient rats. Eur J Nutr 41, 197-202.

18. Reeves PG (1997) Components of the AIN-93 diets as improvements in the AIN-76A diet. J Nutr 127, S838-S841.

19. Loser K, Hansen W, Apelt J, et al. (2005) In vitro-generated regulatory $\mathrm{T}$ cells induced by Foxp3-retrovirus infection control murine contact allergy and systemic autoimmunity. Gene Ther 12, 1294-1304.

20. Bartsch R, Klein D \& Summer KH (1990) The Cd-Chelex assay: a new sensitive method to determine metallothionein containing zinc and cadmium. Arch Toxicol 64, 177-180.

21. Kiyozumi M, Sakaguchi Y, Shiozuka E, et al. (1993) A rapid determination of metallothionein in animal tissues by Cd-Chelex method. Jpn J Toxicol Environ Health 39, 345-349.

22. Ishizaki N, Kotani M, Funaba M, et al. (2011) Hepcidin expression in the liver of rats fed a magnesium-deficient diet. Br J Nutr 106, 1169-1172.

23. Hollander M \& Wolfe DA (1999) Nonparametric Statistical Methods. New York, NY: John Wiley \& Sons.

24. Liuzzi JP, Aydemir F, Nam H, et al. (2006) Zip14 (Slc39a14) mediates non-transferrin-bound iron uptake into cells. Proc Natl Acad Sci U S A 103, 13612-13617.

25. Lichten LA, Liuzzi JP \& Cousins RJ (2009) Interleukin-1 $\beta$ contributes via nitric oxide to the upregulation and functional activity of the zinc transporter Zip14 (Slc39a14) in murine hepatocytes. Am J Physiol Gastrointest Liver Physiol 296, G860-G867.

26. Weglicki WB, Phillips TM, Freedman AM, et al. (1992) Magnesium-deficiency elevates circulating levels of inflammatory cytokines and endothelin. Mol Cell Biochem 110, 169-173.

27. Onosaka S \& Cherian MG (1982) The induced synthesis of metallothionein in various tissues of rats in response to metals. II. Influence of zinc status and specific effect on pancreatic metallothionein. Toxicology 23, 11-20.

28. Kelly EJ, Quaife CJ, Froelick GJ, et al. (1996) Metallothionein I and II protect against zinc deficiency and zinc toxicity in mice. J Nutr 126, 1782-1790.

29. Oh SH, Deagen JT, Whanger PD, et al. (1978) Biological function of metallothionein. V. Its induction in rats by various stresses. Am J Physiol 234, E282-E285.

30. Durnam DM, Hoffman JS, Quaife CJ, et al. (1984) Induction of mouse metallothionein-I mRNA by bacterial endotoxin is independent of metals and glucocorticoid hormones. Proc Natl Acad Sci U S A 81, 1053-1056.

31. Golden BE (1988) Zinc in cell division and tissue growth: physiological aspects. In Zinc in Human Biology, pp. 119-128 [CF Mills, editor]. London: Springer-Verlag. 
32. Min KS, Ueda H \& Tanaka K (2008) Involvement of intestinal calcium transporter 1 and metallothionein in cadmium accumulation in the liver and kidney of mice fed a low-calcium diet. Toxicol Lett 176, 85-92.

33. King JC (1990) Assessment of zinc status. J Nutr $\mathbf{1 2 0}$, $1474-1479$.

34. House WA \& Wastney ME (1997) Compartmental analysis of zinc kinetics in mature male rats. Am J Physiol 273 , R1117-R1125.

35. Mazur A, Maier JA, Rock E, et al. (2007) Magnesium and the inflammatory response: potential physiopathological implications. Arch Biochem Biophys 458, 48-56.
36. Malpuech-Brugère C, Rock E, Astier C, et al. (1998) Exacerbated immune stress response during experimental magnesium deficiency results from abnormal cell calcium homeostasis. Life Sci 63, 1815-1822.

37. Wallach S (1988) Availability of body magnesium during magnesium deficiency. Magnesium 7, 262-270.

38. McAleese DM \& Forbes RM (1961) The requirement and tissue distribution of magnesium in the rat as influenced by environmental temperature and dietary calcium. $J$ Nutr 73, 94-106

39. Nielsen FH (2010) Magnesium, inflammation, and obesity in chronic disease. Nutr Rev 68, 333-340. 